AL IBTIDA: JURNAL PENDIDIKAN GURU MI (2017) VOL. 4(2): 179-188

DOI: http://dx.doi.org/10.24235/al.ibtida.snj.v4i2.1526

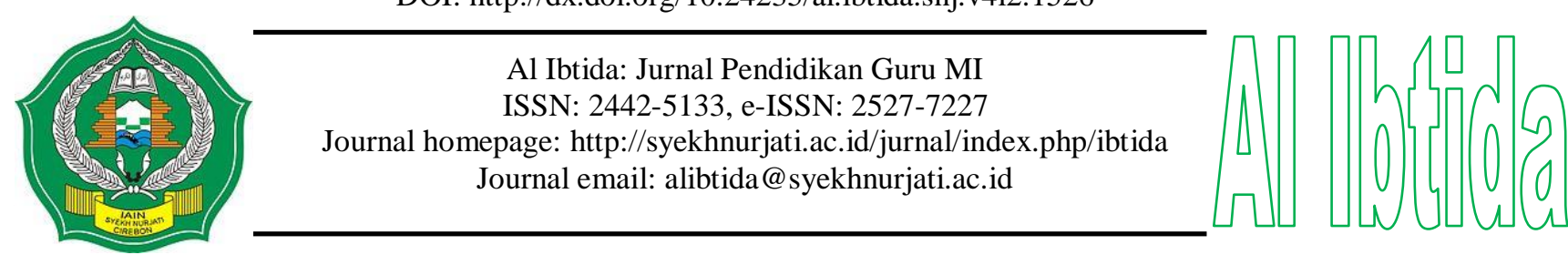

\title{
Meningkatkan Hasil Belajar PKn Siswa Kelas IV Melalui Pembelajaran Kooperatif Make A Match di SDN 15 Batipuh, Kabupaten Tanah Datar
}

\author{
Masrita* \\ *Sekolah Dasar Negeri 15, Batipuh, Kabupaten Tanah Datar, Sumatera Barat \\ Email: masrita07@gmail.com
}

Received 29 May 2017; Received in revised form: 04 October 2017; Accepted 05 October 2017

Publish Online: 27 October 2017

\begin{abstract}
Abstrak
PKn merupakan salah satu mata pelajaran yang kurang dikuasai oleh siswa kelas IV SDN 15 Batipuh. Hal ini terlihat dari hasil belajar siswa pada tahun pelajaran 2015/2016, hanya 44\% siswa yang memenuhi nilai ketuntasan minimal. Kurangnya penguasaan siswa terhadap pelajaran $\mathrm{PKn}$, disebabkan oleh materi pelajaran yang sangat padat, metode belajar yang kurang menarik dan kurangnya minat baca siswa. Berbagai permasalahan tersebut menurut penulis dapat diatasi dengan menerapkan pembelajaran kooperatif make a match. Penelitian terdahulu menunjukkan bahwa metode make a match dapat meningkatkan hasil belajar siswa SD kelas IV pada pelajaran IPS. Tujuan penelitian ini adalah untuk membuktikan apakah pembelajaran kooperatif make a match juga dapat meningkatkan hasil belajar PKn siswa kelas IV SDN 15 Batipuh. Sebanyak 25 siswa kelas IV SDN 15 Batipuh terlibat sebagai sampel dalam penelitian ini. Penelitian dilakukan menggunakan metode kuantitatif dengan pendekatan kuasi eksperimen, one group pretest-posttest design. Penelitian ini membandingkan hasil belajar PKn siswa antara sebelum dan sesudah diberikan intervensi berupa proses pembelajaran menggunakan metode make a match. Hasil penelitian dianalisa dengan menggunakan uji statistik non parametrik wilcoxon signed rank test, menunjukkan metode belajar make a match efektif dalam meningkatkan hasil belajar PKn siswa (mean pretest $=59,60$; mean posttest $=79$, $20 ; \mathrm{p}=0,00<0,05)$. Hasil evaluasi terhadap metode make a match yang diterapkan juga menunjukkan bahwa seluruh siswa merasa terbantu dengan metode yang diterapkan. Oleh karena itu, metode make a match dapat diterapkan pada mata pelajaran lain yang memiliki karakteristik yang serupa dengan pelajaran PKn.
\end{abstract}

Kata kunci: hasil belajar PKn, metode make a match 


\begin{abstract}
PKn is one of the less understood subjects by grade 4 students of SDN 15 Batipuh, seen from the student's learning result in $2015 / 2016$, only $44 \%$ of students fulfill the minimum grade of graduation. Lack of student mastery of the Civics lesson, apperently caused by the number of lesson material that must be submitted, less interesting learning methods and students lack of interest in reading. Those various problems can be overcome by applying cooperative learning models, such as make a match methods. Previous research has shown that make a match method can improve students' learning outcomes in IPS lessons. The aims of this study is to prove whether cooperative learning with make a match method also can improve the PKn learning outcomes of fourth grade students of SDN 15 Batipuh. 25 grade IV students of SDN 15 Batipuh were involved as samples in this study. The research was conducted by using quantitative methode, quasi experimental, one group pretest-posttest design. This study compared the students' learning outcomes between before and after the intervention of learning process using make a match method. The results of the study were analyzed by using nonparametric statistical test of wilcoxon signed rank test, showing the method of learning make a match effective in improving students' learning outcomes (mean pretest $=59,60$; mean posttest $=79,20 ; \mathrm{p}=0,00<0,05)$. The results of the evaluation of the applied make-match method also showed that all students felt helped by the method applied. Therefore, the make a match model can be applied to other subjects that have similar characteristics to the PKn lesson.
\end{abstract}

Keywords: PKn learning outcome, make a match method

\title{
PENDAHULUAN
}

Terdapat lima rumpun mata pelajaran dalam kurikulum, yaitu: agama dan akhlak mulia, kewarganegaraan dan kepribadian, ilmu pengetahuan dan teknologi, estetika, jasmani, olahraga dan kesehatan. Diantara kelima rumpun tersebut, rumpun mata pelajaran kewarganegaraan dan kepribadian seringkali tidak menjadi perhatian utama dalam pendidikan. Padahal, mata pelajaran Pendidikan Kewarganegaraan (PKn) menjadi tonggak awal keikutsertaan kita dalam mencapai tujuan Negara Indonesia seperti yang tercantum dalam pembukaan UUD 1945 alinea 4 dan pasal 31 UUD 1945. PKn merupakan mata pelajaran yang memfokuskan pada pembentukan warga negara yang memahami dan mampu melaksanakan hak-hak dan kewajibannya.

Era globalisasi dan kemajuan teknologi saat ini, PKn menjadi salah satu mata pelajaran dasar yang seharusnya dikuasai oleh siswa demi menumbuhkan kecintaan dan kesadaran sebagai warga negara yang baik. Kenyataan yang ditemui di lapangan, yakni pada siswa kelas IV SD Negeri 15 Batipuh diketahui bahwa PKn menjadi salah satu mata pelajaran yang kurang dikuasai oleh siswa. Hal ini terbukti bahwa hanya $44 \%$ siswa yang mencapai nilai kriteria ketuntasan minimal (KKM) pada tahun pelajaran 2015/2016 lalu. Oleh karena itu, permasalahan hasil belajar pada mata pelajaran PKn siswa kelas IV SDN 15 Batipuh menjadi menarik untuk diteliti. 
Terdapat beberapa masalah yang diperkirakan dapat mempengaruhi hasil belajar PKn siswa yang dapat bersumber dari guru, metode pembelajaran, materi pelajaran maupun siswa. Permasalahan pertama bersumber dari materi pelajaran yang terlalu padat. Terlalu banyak tujuan pembelajaran yang harus dicapai dan materi yang harus dipahami oleh siswa, dapat mempengaruhi kemampuan siswa dalam menyelesaikan tugas maupun menguasai materi pada saat ujian. Permasalahan kedua, terkait dengan metode dan strategi pembelajaran yang kurang sesuai. Para guru PKn seringkali menyampaikan materi dengan cara konvensional (guru menjadi pusat informasi) sehingga pelajaran PKn cenderung membosankan dan kurang menarik perhatian siswa. Hal ini dapat menurunkan minat siswa dalam mengikuti kegiatan belajar mengajar di kelas. Selain itu, permasalahan ketiga terkait dengan kurangnya motivasi dan minat baca siswa terhadap materi pelajaran PKn. Permasalahan ini semakin memperburuk hasil belajar PKn siswa karena tidak hanya selama di kelas, di luar kelas pun siswa menunjukkan kurang tertarik dalam mempelajari materi sehingga mempengaruhi hasil belajarnya.

Berbagai permasalahan yang menyebabkan penurunan hasil belajar PKn tersebut perlu segera diatasi. Kemampuan guru dalam mengelola proses belajar diperkirakan dapat menjadi salah satu solusi dalam menyelesaikan masalah hasil belajar PKn siswa. Menurut Usman (dalam Rusman, 2014), pengelolaan kelas adalah keterampilan guru untuk menciptakan dan memelihara kondisi belajar yang optimal dan mengembalikannya bila terjadi gangguan dalam proses pembelajaran, seperti penghentian perilaku siswa yang memindahkan perhatian kelas, memberikan hadiah bagi siswa yang tepat waktu dalam menyelesaikan tugas atau penempatan norma kelompok yang produktif.

Berdasarkan pengertian tersebut, dapat disimpulkan bahwa proses belajar mengajar menjadi tanggung jawab guru, terutama dalam menciptakan suasana belajar yang komunikaif dan edukatif. Oleh karena itu, guru perlu merancang suatu metode pembelajaran yang tidak membosankan dan dapat menarik minat siswa agar dapat menciptakan suasana yang menyenangkan. Kondisi ini dikenal juga dengan istilah PAKEM (Pembelajaran yang Aktif, Kreatif, Efektif dan Menyenangkan).

Pembelajaran yang aktif menjadi salah satu kunci utama dalam keberhasilan belajar.Trinandita (dalam Nico For Math, 2008), menyatakan bahwa hal yang paling mendasar yang dituntut dalam proses pembelajaran adalah keaktifan siswa. Keaktifan siswa dalam proses pembelajaran akan menyebabkan interaksi yang tinggi antar guru dengan siswa maupun antara sesama siswa itu sendiri. Strategi/metode pembelajaran yang bersifat partisipatoris yang dilakukan guru mampu membawa siswa dalam suasana kelas menjadi segar dan kondusif, dimana masing-masing siswa dapat melibatkan diri semaksimal mungkin. Aktivitas yang timbul dari 
siswa akan mengakibatkan terbentuknya pengetahuan dan keterampilan yangakan mengarah pada peningkatan prestasi.

Salah satu model pembelajaran yang sangat melibatkan siswa dalam proses belajar, adalah model pembelajaran kooperatif. Model pembelajaran kooperatif merupakan suatu model pembelajaran dimana siswa belajar dan bekerja dalam kelompok kecil secara kolaboratif yang anggotanya terdiri atas $4-6$ orang, dengan struktur kelompok heterogen (Slavin dalam Isjoni, 2007). Model pembelajaran ini dilaksanakan melalui sharing proses antara siswa, sehingga dapat mewujudkan pemahaman bersama diantara siswa (Abdulhak dalam Isjoni, 2007). Model pembelajaran kooperatif selain dapat meningkatkan kemampuan kognitif siswa, juga dapat meningkatkan sikap tolong-menolong siswa, belajar untuk saling tukar pendapat, membiasakan diri untuk berani berpendapat dan belajar menghargai pendapat orang lain (Isjoni, 2007).

Terdapat beberapa metode yang dapat diterapkan dalam model belajar kooperatif, seperti: make a match, guided note taking, jigsaw dan sebagainya (Rofiqoh, 2010). Model pembelajaran make a match (membuat pasangan) merupakan salah satu jenis metode pembelajaran kooperatif yang dikembangkan oleh Lorna Curran (dalam Rusman, 2014). Model pembelajaran make a match menggunakan media berupa kartu yang berisi soal/jawaban dari materi yang dipelajari. Siswa diminta untuk mencari pasangan (soal dan jawaban) dari masing-masing kartu tersebut. Model pembelajaran guided note taking merupakan metode pembelajaran menggunakan hand out dimana didalamnya terdapat beberapa poin yang dengan sengaja dikosongkan. Handout tersebut akan dilengkapi oleh siswa selama mendengarkan ceramah guru (Kurnianingsih, 2014). Dalam model pembelajaran jigsaw, guru membagi suatu informasi besar menjadi komponenkomponen kecil. Selanjutnya, siswa akan dibagi menjadi beberapa kelompok kecil dan setiap siswa dalam kelompok bertanggung jawab untuk menguasai satu komponen kecil untuk nanti akan mereka satukan menjadi suatu informasi yang besar (Rofiqoh, 2010). Diantara ketiga metode yang telah dijelaskan, model pembelajaran make a match merupakan model yang paling memperlihatkan keterlibatan siswa secara aktif, termasuk aktivitas fisik.

Penelitian sebelumnya yang dilakukan oleh Priyanto (2015) menunjukkan bahwa metode pembelajaran make a match dapat meningkatkan hasil belajar IPS siswa kelas IV SDN Keniten. Selain itu, penelitian yang dilakukan oleh Kurnianingsih (2014) menunjukkan bahwa metode pembelajaran make a match lebih efektif dalam meningkatkan hasil belajar IPS siswa dibandingkan dengan metode belajar guided note taking. Kedua hasil penelitian tersebut menjadi salah satu dasar bagi peneliti dalam menentukan model pembelajaran yang akan diterapkan dalam mata pelajaran PKn. Metode pembelajaran make a match menurut peneliti juga akan dapat meningkatkan hasil belajar PKn siswa, karena memiliki karakteristik materi yang mirip dengan 
pelajaran IPS. Mata pelajaran PKn dan IPS sama-sama memiliki materi pelajaran yang padat, membutuhkan minat baca yang cukup besar dan kemampuan untuk mengingat materi dengan baik.

Berdasarkan permasalahan yang telah diuraikan di atas, maka peneliti mencoba untuk melakukan penelitian ini dengan tujuan untuk membuktikan apakah pembelajaran kooperatif make a match dapat meningkatkan hasil belajar PKn siswa kelas IV SDN 15 Batipuh, Kabupaten Tanah Datar, Sumatera Barat. Hasil penelitian ini dapat dimanfaatkan sebagai bahan pertimbangan bagi guru dalam memilih metode pembelajaran yang sesuai untuk meningkatkan hasil belajar siswa.

\section{METODE PENELITIAN}

Penelitian ini dilakukan menggunakan metode penelitian kuantitatif dengan pendekatan penelitian kuasi eksperimen, karena dalam penelitian ini terdapat intervensi yang diberikan yaitu berupa model pembelajaran make a match untuk melihat perbedaan hasil belajar siswa pada pelajaran PKn. Metode kuasi tepat digunakan karena pada penelitian ini peneliti tidak melakukan kontrol terlalu ketat terhadap subjek dan tidak dilakukan randomisasi (Kumar, 2011). Desain kuasi eksperimen yang digunakan adalah one group pretest-posttest design (Seniati, Yulianto, \& Setiadi, 2006). Pada penelitian ini, dilakukan perbandingan hasil belajar siswa pada pelajaran PKn antara sebelum dan setelah menerapkanmodel pembelajaranmake a match. Gambaran desain penelitian ini, dapat dilihat pada bagan berikut ini:

$$
\mathrm{O}_{1} \quad \mathrm{X} \quad \mathrm{O}_{2}
$$

Keterangan:

$\mathrm{O}_{1}$ dan $\mathrm{O}_{2} \quad$ : Pengukuran kemampuan belajar dengan memberikan sejumlah soal PKn $\mathrm{X} \quad$ : Intervensi dengan menggunakan pembelajaran kooperatif make a match.

Penghitungan baseline/pretest dilakukan pada tahap awal dari penelitian, yakni siswa diberikan lima soal yang harus dikerjakan setelah mendapatkan sejumlah materi mengenai "Pengenalan lembaga-lembaga negara dalam susunan pemerintahan tingkat pusat". Intervensi yang dilakukan dalam penelitian ini adalah dengan menggunakan pembelajaran kooperatif make a match. Metode pembelajaran make a match dilakukan secara berkelompok, di mana setiap siswa akan mendapatkan sebuah kartu pertanyaan yang harus dicocokkan dengan jawaban yang disedikan pada kartu lain. Terdapat 20 pasang kartu pertanyaan dan jawaban yang harus diselesaikan oleh siswa. Berikut ini merupakan langkah-langkah yang diterapkan dalam metode pembelajaran make a match:

a. Guru menyiapkan beberapa kartu yang berisi beberapa konsep atau topik yang cocok untuk sesi review, sebaliknya satu bagian kartu soal dan bagian lainnya kartu jawaban 
b. Setiap siswa mendapat satu buah kartu dan memikirkan jawaban atau soal dari kartu yang dipegang.

c. Setiap siswa mencari pasangan yang mempunyai kartu yang cocok dengan kartunya (soal jawaban).

d. Setiap siswa yang dapat mencocokkan kartunya sebelum batas waktu diberi poin.

e. Setelah satu babak, kartu dikocok lagi agar tiap siswa mendapat kartu yang berbeda dari siswa yang lain, demikian seterusnya.

Contoh kartu dan jawaban yang digunakan dalam make a match, dapat dilihat pada gambar 1 berikut:

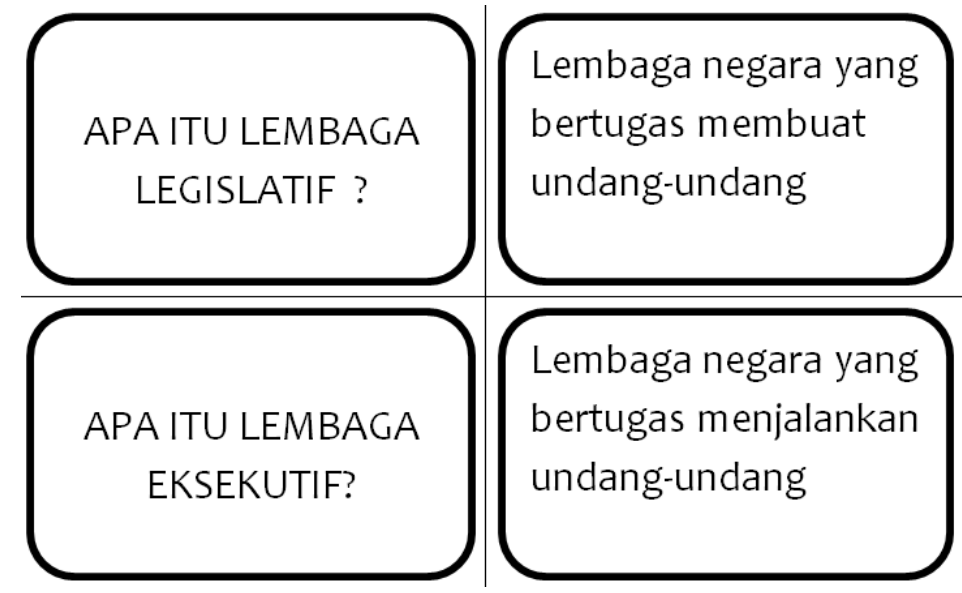

Gambar 1. Contoh kartu make a match

Penelitian ini dilakukan melalui dua tahap, yang disebut dengan istilah siklus I dan siklus II. Setiap siklus terdiri atas dua pertemuan, sehingga penelitian ini dilakukan selama dua bulan pada bulan Januari - Maret 2016. Siklus I merupakan tahapan uji coba yang dilakukan untuk memastikan bahwa siswa memahami instruksi dan pembelajaran make a match. Hasil evaluasi dari siklus I kemudian dijadikan sebagai pertimbangan untuk melakukan revisi dan penyempurnaan pada siklus II. Hasil belajar siswa pada akhir siklus II dijadikan sebagai kondisi posttest. Salah satu perbedaan yang terjadi antara siklus I dan siklus II adalah jumlah anggota kelompok. Pada siklus I, kelas dibagi ke dalam 4 kelompok sehingga jumlah anggota dalam setiap kelompok cukup besar (6 - 7 orang). Hal ini menyebabkan proses belajar dengan model pembelajaran make a match tidak begitu dipahami oleh siswa, sehingga pada siklus II dilakukan perubahan dengan membagi kelas menjadi 6 kelompok (setiap kelompok terdiri atas $4-5$ siswa).

Populasi penelitian ini adalah siswa kelas IV SDN 15 Batipuh. Sampel penelitian adalah 25 siswa kelas IV SDN 15 Batipuh, terdiri atas 15 siswa laki-laki dan 10 siswa perempuan. Pemilihan sampel dilakukan dengan teknik sampling jenuh, yakni jumlah sampel yang dilibatkan 
dalam penelitian sama dengan jumlah populasi (Kumar, 2011). Alasan peneliti menggunakan teknik sampling jenuh adalah karena jumlah populasi yang tidak terlalu besar.

Pengumpulan data dilakukan dengan memberikan lima soal uraian singkat kepada siswa sebagai soal pretest dan posttest. Jawaban siswa kemudian dikoreksi dan diberi nilai dengan rentang 1 -100. Semakin tinggi skor siswa menunjukkan semakin baik hasil belajarnya sebaliknya, semakin rendah skor siswa menunjukkan semakin buruk hasil belajarnya. Selain mengukur hasil belajar siswa, penelitian ini juga menggunakan kuesioner untuk mengetahui penilaian siswa terhadap model pembelajaran yang diterapkan.

Efektivitas pembelajaran make a match dalam mempengaruhi hasil belajar PKn siswa, dilakukan uji beda antara rata-rata skor awal (pretest) dan skor setelah siklus II (post test). Uji hipotesa dilakukan dengan menggunakan metode statistik non parametrik Wilcoxon Signed Rank Test dengan menggunakan software SPSS 20. Teknik analisa statistik ini digunakan karena penelitian melibatkan jumlah sampel yang sedikit (kurang dari 30), bertujuan untuk membandingkan skor individu pada dua kondisi yang berbeda (pretest-post test). Selain uji beda, penelitian ini juga menggunakan statistik deskriptif untuk mendapatkan gambaran penilaian siswa terhadap pembelajaran make a match yang digunakan.

\section{HASIL DAN PEMBAHASAN}

\section{A. Hasil Belajar PKn Siswa}

Deskripsi hasil belajar siswa pada saat awal, siklus I dan siklus II dapat dilihat pada tabel berikut ini:

Tabel 1. Deskripsi Hasil Belajar PKn Siswa

\begin{tabular}{lrrrr}
\hline \multicolumn{1}{c}{ Hasil Belajar } & \multicolumn{1}{c}{ Minimum } & Maximum & Rata-rata & Std. Deviation \\
\hline Awal (pretest) & 20 & 95 & 59,60 & 23,315 \\
\hline Siklus1 & 20 & 100 & 70,60 & 18,219 \\
\hline Siklus2(posttest) & 40 & 100 & 79,20 & 17,361 \\
\hline
\end{tabular}

Berdasarkan tabel 1, diketahui bahwa terdapat perbedaan hasil belajar siswa pada mata pelajaran PKn antara sebelum dan setelah diterapkan pembelajaran kooperatif make a match. Pada saat pretest diketahui bahwa nilai terendah yang diperoleh siswa adalah 20, sedangkan saat post test nilai terendah yang diperoleh siswa adalah 40. Rata-rata hasil belajar siswa juga mengalami peningkatan, dari 59,60 menjadi 79,20.

\section{B. Uji Hipotesa Peningkatan Hasil Belajar Siswa dengan Pembelajaran Kooperatif Make a} Match

Hasil uji hipotesis dengan menggunakan bantuan software SPSS 20, dapat dilihat pada tabel berikut ini: 
Tabel 2. Hasil Uji Hipotesa Penelitian

Hypothesis Test Summary

\begin{tabular}{|c|c|c|c|c|}
\hline & Null Hypothesis & Test & Sig. & Decision \\
\hline 1 & $\begin{array}{l}\text { The median of differences betwe } \\
\text { siklus } 2 \text { and awal equals } 0 \text {. }\end{array}$ & $\begin{array}{l}\text { Related- } \\
\text { Samples } \\
\text { ofulilcoxon } \\
\text { Signed Rank } \\
\text { Test }\end{array}$ & .000 & $\begin{array}{l}\text { Reject the } \\
\text { null } \\
\text { hypothesis. }\end{array}$ \\
\hline
\end{tabular}

Asymptotic significances are displayed. The significance level is ,05.

Dari Tabel 2 di atas, diperoleh bahwa kesimpulan dari hasil uji hipotesis adalah penolakan hipotesa null atau penerimaan hipotesa alternatif penelitian. Dengan demikian, dapat disimpulkan bahwa terdapat perbedaan yang signifikan pada hasil belajar siswa antara sebelum (awal/pretest) dengan sesudah diterapkan (siklus II/postest) pembelajaran kooperatif make a match. Artinya, pembelajaran kooperatif make a match efektif dalam meningkatkan hasil belajar PKn siswa kelas IV SDN 15 Batipuh, terlihat dari peningkatan rata-rata hasil belajar siswa pada saat siklus II.

Hasil penelitian ini sejalan dengan hasil penelitian yang pernah dilakukan oleh beberapa peneliti sebelumnya, seperti: penelitian yang dilakukan oleh Hermanto (2011) dan Priyanto (2015) pada sampel siswa SD kelas IV. Hasil penelitian Hermanto (2011) menunjukkan bahwa metode belajar make a match efektif dalam meningkatkan kemampuan siswa kelas IV SD dalam belajar PKn. Metode make a match juga efektif dalam meningkatkan kemampuan siswa kelas IV SD dalam belajar IPS (Priyanto, 2015).

Metode make a match termasuk dalam model pembelajaran kooperatif. Model pembelajaran kooperatif merupakan model pembelajaran yang lebih banyak melibatkan aktivitas siswa, sedangkan guru hanya menjadi fasilitator dalam belajar. Model pembelajarn ini dapat membantu siswa dalam mengembangkan pengetahuan, sikap, keterampilan sosial yang bermanfaat bagi kehidupan bermasyarakat (Rofiqoh, 2010). Oleh karena itu, metode belajar kooperatif harus dilakukan dalam bentuk aktivitas kelompok (Isjoni, 2007). Semakin tinggi keterlibatan siswa dalam aktivitas belajar, maka akan semakin banyak modalitas belajar yang digunakan sehingga lebih memudahkan siswa dalam mengingat materi yang diajarkan.

Pembelajaran kooperatif make a match memiliki beberapa kelebihan dibandingkan dengan model belajar lainnya, seperti: menciptakan suasana belajar yang aktif dan menyenangkan serta menarik perhatian siswa (Rofiqoh, 2010). Kelebihan-kelebihan dari model belajar ini dapat membantu siswa dalam meningkatkan hasil belajarnya, seperti yang terlihat pada hasil penelitian ini. Rata-rata hasil belajar siswa pada saat siklus II jauh 
meningkatkan dibandingan dengan saat sebelum diterapkan model pembelajaranmake $a$ match. Hasil observasi selama penelitian menunjukkan bahwa siswa juga lebih antusias ketika belajar dengan pembelajaran kooperatif make a match. Hasil observasi ini juga didukung oleh evaluasi positif yang diberikan oleh siswa terhadap model pembelajaran yang diterapkan. Berikut ini adalah ringkasan penilaian siswa terhadap pembelajaran kooperatif make a match:

Tabel 3. Lembar Evaluasi Siswa

\begin{tabular}{lllc}
\hline \multirow{2}{*}{ No } & \multicolumn{1}{c}{ Pernyataan } & \multicolumn{2}{c}{ Jawaban } \\
\cline { 2 - 4 } & \multicolumn{1}{c}{ Ya } & Tidak \\
\hline 1 & Apakah kamu senang dengan pembelajaran yang kamu ikuti ? & $80 \%$ & $20 \%$ \\
\hline 2 & $\begin{array}{l}\text { Apakah dengan cara pembelajaran ini, memudahkan kamu } \\
\text { memahami materi pembelajaran? }\end{array}$ & $72 \%$ & $28 \%$ \\
\hline 3 & $\begin{array}{l}\text { Apakah media yang digunakan guru dapat membantu pemahaman } \\
\text { kamu terhadap materi pembelajaran? }\end{array}$ & $\mathbf{1 0 0 \%}$ & 0 \\
\hline 4 & $\begin{array}{l}\text { Apakah kamu mengalami kesulitan dalam pembelajaran model } \\
\text { make a match ini? }\end{array}$ & $92 \%$ & $8 \%$ \\
\hline 5 & $\begin{array}{l}\text { Apakah kerja kelompok yang kamu ikuti dapat melatih keberanian, } \\
\text { kerjasama, dan keaktifan mu dalam belajar? }\end{array}$ & $88 \%$ & $12 \%$ \\
\hline 6 & $\begin{array}{l}\text { Apakah kamu menyukai model pembelajaran yang ditampilkan guru } \\
\text { mu? }\end{array}$ & $96 \%$ & $4 \%$ \\
\hline 7 & $\begin{array}{l}\text { Apakah proses kegiatan belajar yang kamu ikuti, dapat } \\
\text { meningkatkan aktivitas dan semangat belajar mu ? }\end{array}$ & $\mathbf{1 0 0 \%}$ & 0 \\
\hline 8 & $\begin{array}{l}\text { Apakah kamu mendapat bimbingan dari guru jika mengalami } \\
\text { kesulitan ? }\end{array}$ & $96 \%$ & $4 \%$ \\
\hline 9 & $\begin{array}{l}\text { Apakah dengan pembelajaran kooperatif model make a match ini } \\
\text { dapat meningkatkan hasil belajar mu ? }\end{array}$ & $84 \%$ & $16 \%$ \\
\hline 10 & Apakah kamu memahami pertanyaan yang diberikan guru ? & 96 & $4 \%$ \\
\hline
\end{tabular}

Berdasarkan tabel 3, dapat disimpulkan bahwa secara umum siswa memberikan penilaian positif terhadap pembelajaran kooperatif make a match. Seluruh siswa mengaku bahwa media kartu yang digunakan dapat membantu mereka dalam memahami materi pelajaran yang disampaikan. Seluruh siswa juga menilai bahwa pembelajaran kooperatif make a match dapat meningkatkan aktivitas dan semangat belajar mereka, termasuk ketika belajar PKn yang umumnya dinilai membosankan. Sebagian besar siswa merasa senang dengan model pembelajaran yang diterapkan. Meskipun demikian, sebagian besar siswa (92\%) menilai bahwa pembelajaran kooperatif make a match sulit untuk diterapkan. Oleh karena itu, mereka masih sangat membutuhkan bimbingan dari guru untuk dapat menyelesaikan kesulitan yang ditemui. 


\section{SIMPULAN}

Berdasarkan hasil penelitian yang telah dilakukan, dapat disimpulkan bahwa pembelajaran kooperatif make a match dapat meningkatkan hasil belajar PKn siswa kelas IV SDN 15 Batipuh. Terjadi peningkatan rata-rata hasil belajar siswa dari 59,6 menjadi 79,2. Sebagian besar siswa merasa sangat terbantu dengan pembelajaran kooperatif make a match dalam meningkatkan hasil belajar, karena metode yang digunakan dapat membuat mereka lebih aktif dalam belajar, membantu dalam memahami pelajaran dan suasana belajar terasa lebih menyenangkan. Dengan demikian, pembelajaran kooperatif make a match seharusnya juga dapat diterapkan di berbagai mata pelajaran lainnya untuk dapat meningkatkan hasil belajar siswa. Meskipun dinilai menyenangkan, namun metode belajar ini tidak mudah dipahami oleh siswa sehingga guru tetap perlu melakukan pengawasan dan memberikan arahan selama proses belajar berlangsung. Sehingga, kesiapan guru juga menjadi salah satu faktor penting yang perlu dipertimbangkan dalam menerapkan pembelajaran kooperatif make a match.

\section{DAFTAR PUSTAKA}

Hermanto, B. (2011). Efektivitas Metode Cooperative Learning Tipe Make A Match terhadap Aktivitas dan Hasil Belajar Mate Pelajaran Pendidikan Kewarganegaraan Materi Globalisasi di SD Negeri Kaligangsa Kulon 01 Brebes. Semarang: Universitas Negeri Semarang.

Isjoni. (2007). Pembelajaran Visioner (Perpaduan Indonesia-Malaysia). Yogyakarta: Pustaka Pelajar.

Kementrian Pendidikan Nasional. (2006). Peraturan Menteri Pendidikan Nasional Nomor 22 Tahun 2006.

Kumar, R. (2011). Research Methodology: a Step by Step Guide for Beginners. London: SAGE.

Kurnianingsih, E. (2014). Perbedaan Efektivitas Metode Make A Match dan Metode Guided Note Taking dalam Meningkatkan Aktivitas dan Hasil Belajar Siswa pada Pembelajaran IPS di Kelas VIII SMP 2 Bantul Tahun Ajaran 2013/2014. Yogyakarta: Universitas Negeri Yogyakarta.

Nico For Math. 2008. Keaktifan Siswa. Diakses dari: (http://ipotes.wordpress.com/2008/05/24/prestasi-belajar/).

Priyanto, A. (2015). Peningkatan Prestasi Belajar Siswa dengan Model Pembelajaran Kooperatif Tenkin Mencari Pasangan pada Pelajaran IPS di Kelas IV SD Negeri Keniten Tahun Pelajaran 2013/2014. Yogyakarta: Universitas Sanata Dharma

Rofiqoh, F. (2010). Efektivitas Pembelajaran Kooperatif Mode Make A Match dalam Meningkatkan Hasil Belajar Siswa Pada Mata Pelajaran IPS. Jakarta: UIN Syarif Hidayatullah.

Rusman. (2014). Model - Model Pembelajaran. Jakarta: PT Raja Grafindo.

Seniati, L., Yulianto, A., \& Setiadi, B. N. (2006). Psikologi Eksperimen. Jakarta: PT INDEKS. 